\title{
Severe MCA stroke without MCA occlusion?
}

Thrombectomy uncovers accessory middle cerebral artery

\section{Figure 1 Conventional angiography}

A
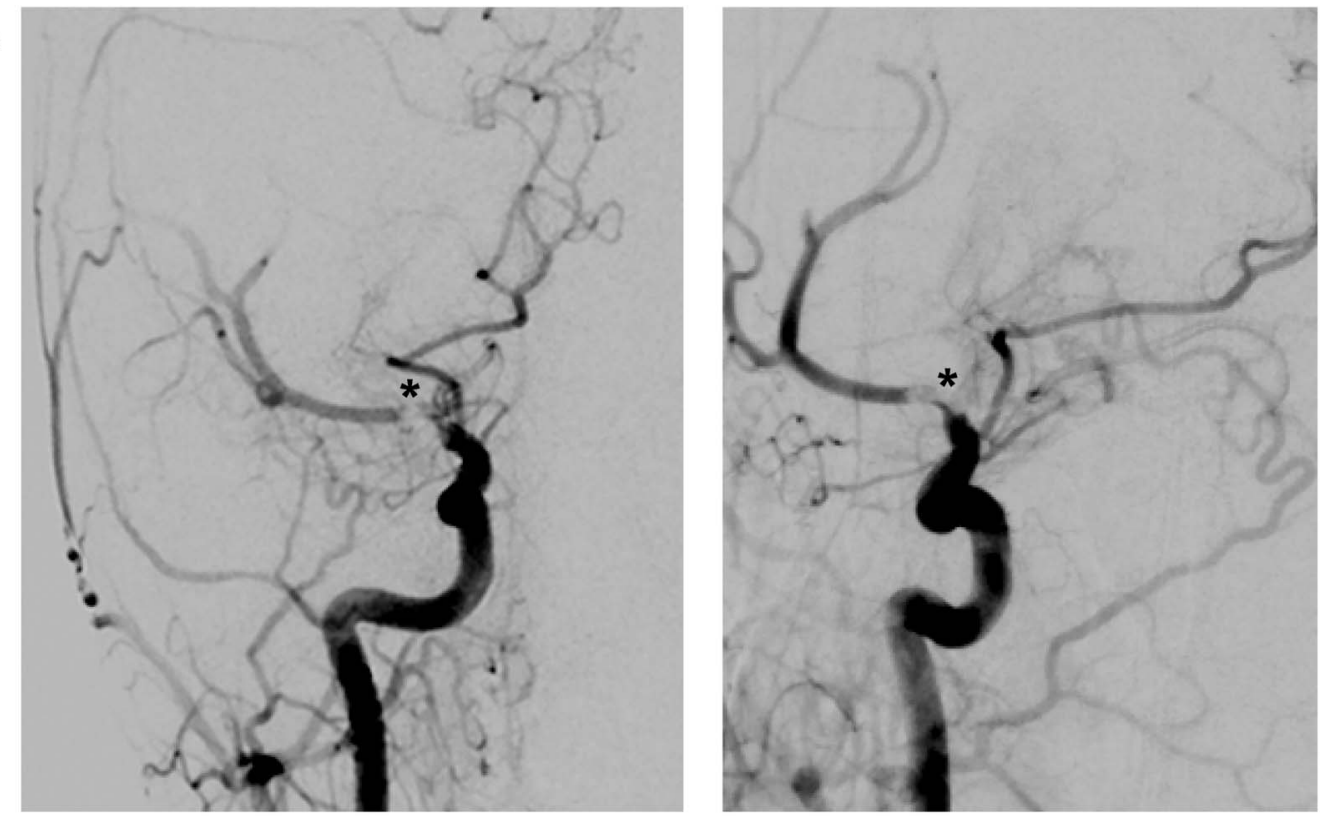

B
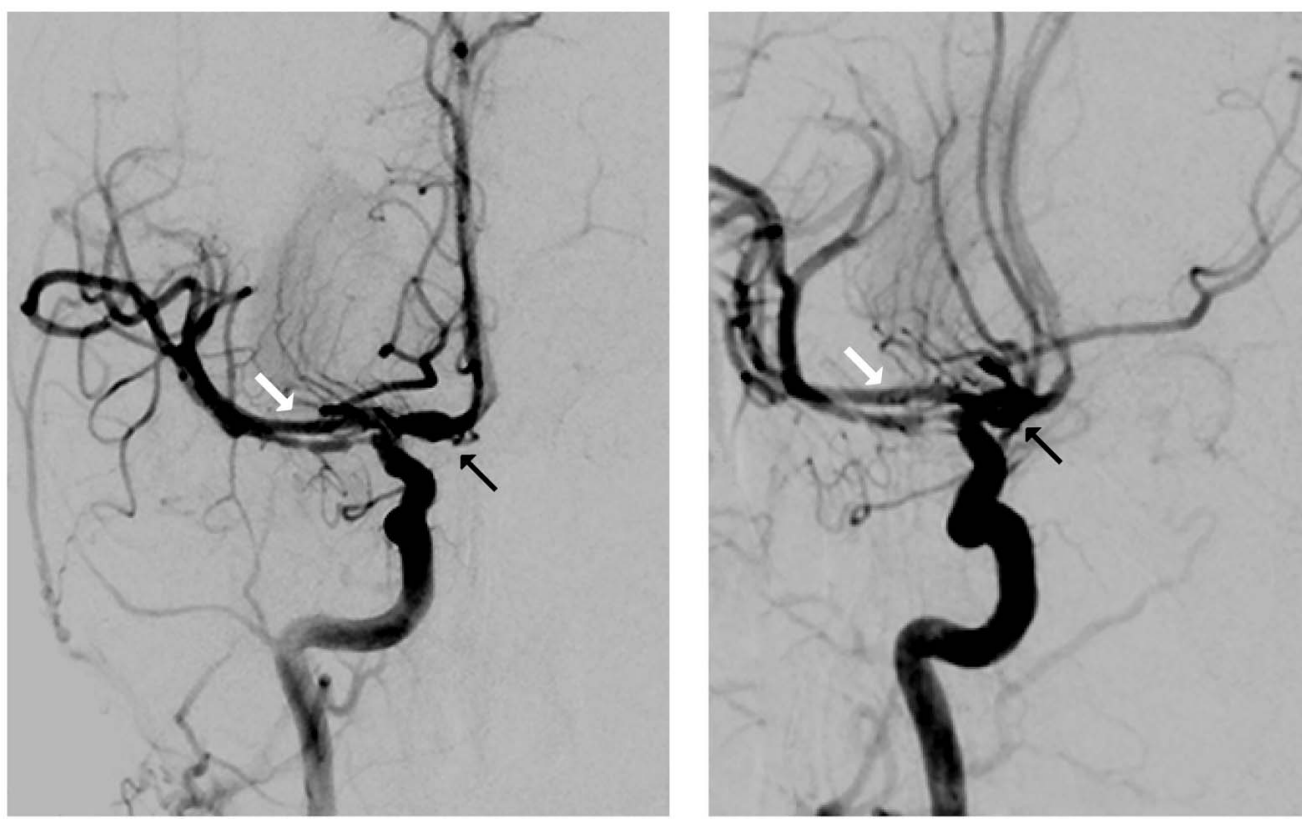

(A) Conventional angiography demonstrates the thrombus $\left(^{*}\right)$ at the right internal carotid artery bifurcation occluding the anterior cerebral artery but right middle cerebral artery was well-perfused. (B) After thrombectomy, an accessory middle cerebral artery (white arrow) originating from the right A1 segment (black arrow) was uncovered. 

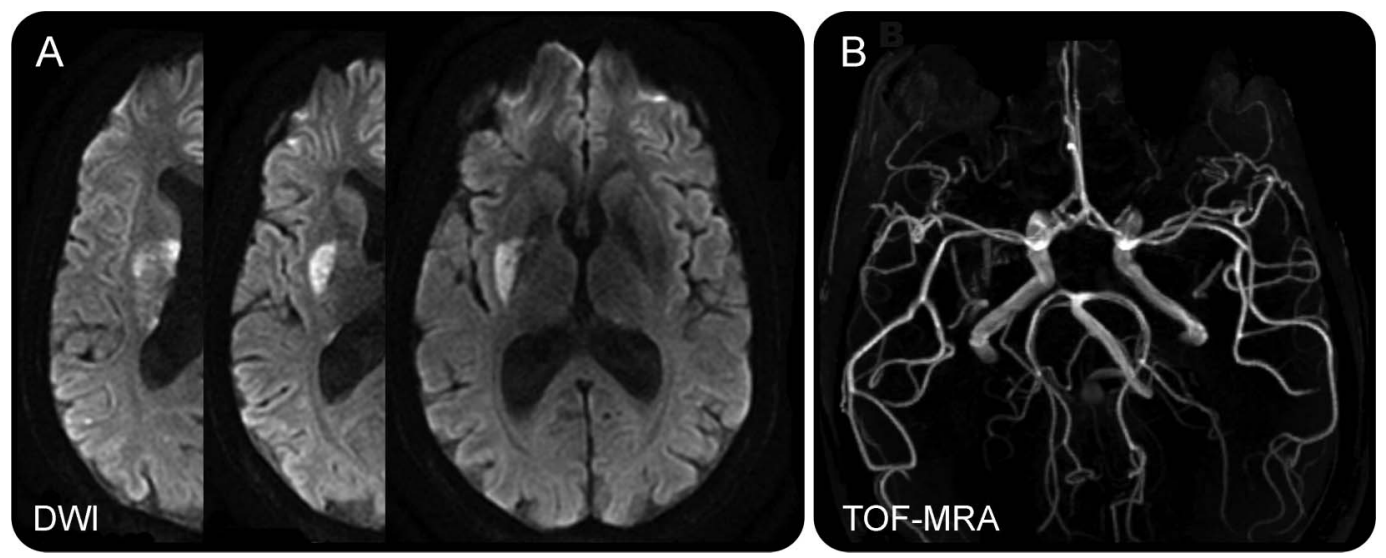

(A) The next day's MRI with diffusion-weighted imaging (DWI) sequences demonstrates an infarction restricted to the lenticulostriate territory. (B) Time-of-flight magnetic resonance angiography (TOF-MRA) reveals the accessory middle cerebral artery in the right and a duplicated middle cerebral artery in the left hemisphere.

A 21-year-old woman presented with dysarthria and severe left-sided hemiparesis. CT angiography detected a thrombus at the right distal internal carotid artery, but a well-perfused middle cerebral artery (MCA). The mechanism of the clinical presentation was therefore uncertain. IV thrombolysis was performed but she did not improve. Subsequent thrombectomy uncovered an accessory MCA originating from the A1 segment (figure 1). Neurologic deficits improved promptly and MRI demonstrated a lenticulostriate infarction (figure 2). Accessory MCA is an anatomical variant occurring in $0.4 \% .{ }^{1}$ This case illustrates that knowledge of rare variants may become important especially in the emerging era of mechanical thrombectomy.

Anna Bayer-Karpinska, MD, Jürgen Lutz, MD, Tobias Birnbaum, MD, Marianne Dieterich, MD, FANA, Frank Arne Wollenweber, $M D$

From Ludwig-Maximilians-University (A.B.-K., J.L., M.D., F.A.W.), Munich; and Helios Amper-Klinikum (T.B.), Dachau, Germany.

Author contributions: A. Bayer-Karpinska drafted, wrote, and revised the manuscript. J. Lutz examined the images, treated the patient, and revised the manuscript. T. Birnbaum, M. Dieterich, and F.A. Wollenweber made substantive intellectual contribution to the case report by treating the patient and revising the manuscript.

Study funding: No targeted funding reported.

Disclosure: A. Bayer-Karpinska, J. Lutz, T. Birnbaum, and M. Dieterich report no disclosures relevant to the manuscript. F.

Wollenweber served as a consultant and received travel expenses from Boehringer Ingelheim. Go to Neurology.org for full disclosures.

Correspondence to Dr.Bayer-Karpinska: anna.bayer@med.uni-muenchen.de

1. Komiyama M, Nakajima H, Nishikawa M, Yasui T. Middle cerebral artery variations: duplicated and accessory arteries. AJNR Am J Neuroradiol 1998;19:45-49.

\section{New Payment and Delivery Models}

How can you ensure your first value-based contract is a success? Check out the AAN's Top 5 tips to get on the right track!

Link to - https://www.aan.com/practice/top-five/ 


\title{
Neurology
}

\author{
Severe MCA stroke without MCA occlusion?: Thrombectomy uncovers accessory \\ middle cerebral artery \\ Anna Bayer-Karpinska, Jürgen Lutz, Tobias Birnbaum, et al. \\ Neurology 2015;85;831-832 \\ DOI 10.1212/WNL.0000000000001894
}

This information is current as of August 31, 2015

Updated Information \&
Services
References
Citations
Subspecialty Collections

Permissions \& Licensing

Reprints including high resolution figures, can be found at: http://n.neurology.org/content/85/9/831.full

This article cites 1 articles, 0 of which you can access for free at: http://n.neurology.org/content/85/9/831.full\#ref-list-1

This article has been cited by 2 HighWire-hosted articles: http://n.neurology.org/content/85/9/831.full\#\#otherarticles

This article, along with others on similar topics, appears in the following collection(s):

Infarction

http://n.neurology.org/cgi/collection/infarction

MRI

http://n.neurology.org/cgi/collection/mri

Other cerebrovascular disease/ Stroke

http://n.neurology.org/cgi/collection/other_cerebrovascular_disease_st roke

Stroke in young adults

http://n.neurology.org/cgi/collection/stroke_in_young_adults

Information about reproducing this article in parts (figures,tables) or in its entirety can be found online at:

http://www.neurology.org/about/about_the_journal\#permissions

Information about ordering reprints can be found online:

http://n.neurology.org/subscribers/advertise

Neurology ${ }^{\circledR}$ is the official journal of the American Academy of Neurology. Published continuously since 1951, it is now a weekly with 48 issues per year. Copyright () 2015 American Academy of Neurology. All rights reserved. Print ISSN: 0028-3878. Online ISSN: 1526-632X.

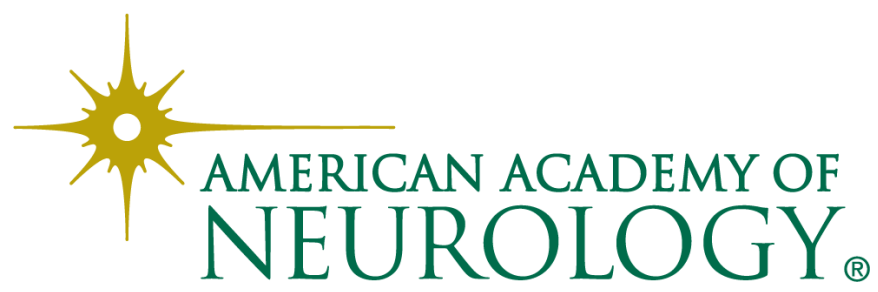

